\title{
Development of Higher Molecular Weight of Recombinant Human Interferon Alpha-2a by Albumin Fusion Technology in Methilotropic Yeast Pichia Pastoris
}

\author{
Ratih Asmana Ningrum ${ }^{\#}$, Neng Herawati ${ }^{\#}$, Andri Wardiana ${ }^{\#}$ \\ ${ }^{\#}$ Research Center for Biotechnology Indonesian Institute of Science, Cibinong Science Center \\ Jl Raya Bogor Km 46 Cibinong Bogor 16911, Indonesia \\ E-mail: ratih.asmana@gmail.com/rati004@lipi.go.id
}

\begin{abstract}
Human interferon alpha-2a (hIFNa-2a) is a therapeutic protein that used in cancer and hepatitis B/C treatments. One main problem of using hIFNa-2a is the lack of good pharmacokinetic profile due to its low molecular weight. This research aims to develop recombinant hIFNa-2a fusion protein by using human serum albumin (HSA) to improve its molecular weight. The codon optimized open reading frame (ORF) encoding fusion protein constructed synthetically and inserted into pPICZaB expression vector and transformed into Escherichia coli XL1-blue. The characterized recombinant plasmid was linearized and transformed into methilotropic yeast Pichia pastoris GS115 and SMD 1168. The expression analysis showed that the best expression was achieved by protease deficient strain SMD1168. Molecular weight characterization informed that the fusion protein was $85 \mathrm{kDa}$ in size as its theoritical size. Western blotting methods confirmed the identity of fusion protein based on the recognition by anti HSA and anti hIFNa-2 antibodies. This result strongly indicated that the fusion protein was successfully produced in Pichia pastoris. Protein quantification informed that the protein yield was $14 \mathrm{mg} / \mathrm{L}(O D 600=2)$. Stability expression analysis showed that protein production was stable until $60^{\text {th }}$ generations. Preliminary antiproliverative activity assay demonstrated that the fusion protein had $20 \%$ lower activity comparing to non fusion form.
\end{abstract}

Keywords — human interferon alpha-2a; human serum albumin; fusion protein; antiproliverative; Pichia pastoris.

\section{INTRODUCTION}

Cancer and hepatitis infection are major public health problem worldwide. It was reported that approximately 14.1 million cancer cases occur worldwide with 8.2 million of death and about $64 \%$ of the death arise in developing countries. Currently, the global population for hepatitis is 6 billions for Hepatitis B and 150 millions for Hepatitis C with 1.5 million of death [1], [2]. hIFN $\alpha-2 \mathrm{a}$ is a cytokine that widely used in hepatitis and cancer treatments. It is a glycoprotein that consists of 165 amino acids with $19 \mathrm{kDa}$ in size. Despite its wide biological activity as antivirus, antiproliferation, and immunomodulation, the protein still has major limitation due to rapid renal clearance [3]. As low molecular weight protein, the major elimination route of protein in the body is through renal filtration system by glomerulus [4]. Glomerulus filtration is selective to protein size and charge. Glomerulus filter is composed of three layers, namely the endothelial layer, the basal membrane, and the slit diaphragm. Glomerulus basement membrane has large protein molecules such as laminin, collagen type IV, entactin and sulfate proteoglycans that have negative charges and contribute to charge selectivity. Slit diaphragm has $4 \mathrm{x}$ $14 \mathrm{~nm}$ pore size which contributes on size selectivity [5].

The elimination half-life of commercial unmodified rhIFN $\alpha-2 a$ (Roferon ${ }^{\circledR}$, Roche) which is given intravenously is 5 hours. The consequence of short half-life time is high of frequency treatment to maintain the effective concentration of the protein. The frequency of rhIFN $\alpha-2 a$ treatment is dependent upon the diseases. The frequency of treatment for hepatitis B or C is three times per week for 24 to 48 weeks and for the oncological indication is daily from several months to a year or longer [6]. Moreover, frequent treatment produces several dose dependent side effects, such as toxicity to the skin, nervous, endocrine, and immune problems [3], [6], [7].

The strategies to improve the elimination half-life time of rhIFN $\alpha$-2a have been done with a wide variety of protein modification approach, such as higher molecular weight by pegylation, protease resistant variants by amino acid substitution and more negatively charge by glycosilation. The most successful modification is protein conjungation by polyethylene glycol (PEG). The commercial pegylated protein is a larger molecule, PEGASYS (Hoffman La Roche, 
UK), which has branched $40 \mathrm{kDa}$ PEG molecule with 70 hours of elimination half life. PEGASYS decreases the therapy frequency for only once a week though it only retains $7 \%$ of $E$. coli derived protein activity [6], [7]. The most shortcoming of pegylation is product heterogeneity due to different PEG binding position in the protein. Another modification in rhIFN $\alpha-2 \mathrm{a}$ is glycosylation which not only increases the protein molecular weight but also changes the total charge into more negative [3].

Albumin-fusion technology is a rational, simple and flexible alternative platform to modify rhIFN $\alpha-2 a$. The technology is purposed to increase the protein molecular weight through a fusion between rhIFN $\alpha-2 a$ and human serum albumin (HSA). HSA is the major protein in blood plasma that is produced by the liver and plays a role in maintaining blood osmolarity and carry small molecules [8]. HSA is chosen because it has a 9 day long half-life in the body, widely distributed and is not immunogenic. Moreover, it may improve the solubility and stability of the protein [9]. There are some proteins that used albumin-fusion technology to improve molecular weight and elimination half-life, such as insulin, p53, recombinant factor VIII, recombinant factor IX, Somatostatin, VEGF165b, growth hormone, granulocyte colony stimulating factor, interferon alpha-2b, interleukin 2, glucagon-like peptide and $\beta$ natriuretic peptide [10], [11], [12], [13], [14], [15], [16].

A previous study in Albuferon (HGSI, Novartis) as a fusion protein of rhIFN $\alpha 2 b$ with HSA reported that the protein elimination half-life is increasing until 159 hours although the protein failed and withdrawn in clinical assay phase II. This long elimination half-life can decrease the frequency of therapy into once in two weeks [16]. The albumin fusion technology has widely used as a fusion partner to extend in vivo half-life of protein therapeutics and both the $\mathrm{N}$ terminal and $\mathrm{C}$ terminal. Zhao et al claimed that HSA fusion at the N-terminal of rhIFN $\alpha-2 a$ caused heterogeneity due to the disruption of the disulfide bond between cysteine at positions 1 to 98 . This causes instability that promotes aggregation so the formulation must be in lyophilized form which requires additional freeze-drying process, additional time and cost. Instability of these proteins also causes low recovery during the purification process. Heterogeneity in HSA-hIFN $\alpha-2 b$ fusion protein can be avoided by adding a linker between the two proteins or changing the orientation of HSA fusion at the N-terminal into C-terminal [8], [9].

This research was purposed to develop higher molecular weight of rhIFN $\alpha$-2a by using HSA fusion technology in methilotropic yeast Pichia pastoris. The codon optimized open reading frame encoding fusion protein with HSA orientation at the $\mathrm{C}$ terminal of rhIFN $\alpha$-2a. Two different strains of Pichia pastoris were used : GS115 and protease deficient strain SMD1168 as protein production host to obtain best expression level. So far there was no study reported the use of two different hosts for production of rhIFN $\alpha-2 a-H S A$ in Pichia pastoris. Yang et al used SMD1168 to produce human interferon alpha-2bthymosin $\alpha 1$ fusion protein and $\mathrm{Yu}$ et al applied the same strain to obtain interferon alpha-2b-HSA [17], [18]. Several publications also reported GS115 as production host of interferon alpha-2b-HSA fusion protein [8], [18], [19].

\section{MATERIALS AND METHODS}

\section{A. Strains and Media}

The E. coli that used for cloning purpose was XL1blue (Stratagene, USA). The cultivation media was low salt LB ( $1 \%$ tryptone, $0.5 \%$ yeast extract and $1 \% \mathrm{NaCl}$ ) and the selection media was low salt LB agar with $25 \mu \mathrm{g} / \mu \mathrm{L}$ of zeocin (Invitrogen, USA). Pichia pastoris that used as production host were wildype X33, mutant GS115 and protease deficient SMD1168 (Invitrogen, USA). Cultivation media was YPD (1\% yeast extract, $2 \%$ peptone, $2 \%$ dextrose), screening media was YPDS (1\% yeast extract, $2 \%$ peptone, $2 \%$ dextrose, $1 \mathrm{M}$ sorbitol) containing zeocin from 500 to $2000 \mu \mathrm{g}$, and expression medias were BMGY (1\% yeast extract, $2 \%$ peptone, $100 \mathrm{mM}$ potassium phosphate $\mathrm{pH}$ $6,1.34 \%$ YNB, $1 \%$ glycerol, $0.2 \%$ Biotin), and BMMY that consist of $1 \%$ yeast extract, $2 \%$ peptone, $1.34 \% \mathrm{YNB}, 0.2 \%$ Biotin and $0.5 \%$ methanol, respectively. The protease inhibitor that added during the expression was a complete ultra-tablet (Roche, Germany).

\section{B. Construction of ORF and Transformation into P. pastoris}

Codon optimized ORF encoding fusion protein was constructed synthetically by IDT (Singapore) and inserted in PUC-IDT cloning vectors. The ORF was sub cloned into pPICZ $\alpha \mathrm{B}$ expression vector and transformed into $E$. coli XL1 blue. The transformants were selected in low salt LB agar containing $25 \mu \mathrm{g} / \mathrm{mL}$ of zeocin. Recombinant plasmids were isolated and characterized based on their molecular weight and XhoI-EcoR 1 restriction sites. The recombinant plasmid was linearized by $S a c$ I restriction enzyme and purified by using phenol-chloroform precipitation. $10 \mu \mathrm{g}$ of linearized plasmid was transformed into Pichia pastoris cells by electroporation (BioRad) at $2000 \mathrm{~V}$. The transformants were selected in YPDS medium containing $100 \mu \mathrm{g} / \mathrm{ml}$ of zeocin at $30^{\circ} \mathrm{C}$ for $24-48 \mathrm{~h}$. The selected colonies were further screened to select the highest copy number in YPDS medium containing 500, 1000 and $2000 \mu \mathrm{g}$ of zeocin.

\section{Expression Analysis and Protein Characterization}

A single colony was cultivated in $2 \mathrm{ml} \mathrm{BMGY}$ at $30^{\circ} \mathrm{C}$ and $250 \mathrm{rpm}$ for $24 \mathrm{~h}$. The pellet was collected, resuspended in $2 \mathrm{ml}$ BMMY $(\mathrm{OD}=1)$ and cultivated at the same condition. Methanol $(0.5 \%)$ was added at $24 \mathrm{~h}$ of cultivation time. The supernatant was collected by centrifugation at $1500 \mathrm{x}$ g for 5 min. Protein supernatant was collected and characterized by SDS- PAGE and Slot Blot methods to monitor protein expression and verify its identity. SDS-PAGE was performed by using $10 \%(\mathrm{w} / \mathrm{v})$ polyacrylamide gel and coomassie blue staining solution (BioRad). 1: 1000 dilution of mouse anti IFNa-2 (Merck 407290-500 UGCN, Germany ) or 1:1000 dilution of mouse anti HSA (Sigma) and 1: 7500 dilution of anti mouse IgG alkaline phosphatase conjugate (Promega, USA) with NBT/BCIP detection (Merck, Germany) were applied in Slot Blot method.

\section{Stability Expression, Overproduction, and Purification}

The replica plating method was used to check the stability expression of ORF encoding fusion protein. We used YPD media containing $100 \mu \mathrm{g} / \mathrm{mL}$ of zeozin. The expression 
monitoring was performed for each $10^{\text {th }}$ generation. Overproduction was applied by using shake flask method with $50 \mathrm{~mL}$ of BMMY media. A single colony was grown overnight in $25 \mathrm{ml} \mathrm{BMGY}$ medium at $30^{\circ} \mathrm{C}$ and $250 \mathrm{rpm}$ until log phase $\left(\mathrm{OD}_{600}=2-6\right)$. The culture was centrifuged at $1500 \mathrm{x} \mathrm{g}$ for $5 \mathrm{~min}$. The pellet was resuspended in $50 \mathrm{ml}$ BMMY medium $\left(\mathrm{OD}_{600}=1.0\right.$ containing $0.5 \%$ methanol as inducer). We used two different harvesting time $24 \mathrm{~h}$ and 48 $\mathrm{h}$ after the induction. The $48 \mathrm{~h}$ harvesting time was carried out by repeating the induction after $24 \mathrm{~h}$ cultivation time. Harvesting was performed by centrifugation at $1500 \mathrm{x} g$ for 5 minutes at room temperature. Supernatant containing fusion protein was collected and concentrated $10 \mathrm{X}(\mathrm{v} / \mathrm{v})$ by using tangential filtration system with $10 \mathrm{kDa}$ molecular weight cut off. The concentrated protein was purified by using affinity chromatography method by blue sepharose 6 fast flow (Capto blue, GE healthcare, Germany). Sample $\mathrm{pH}$ was adjusted to neutral $\mathrm{pH}$, filtered through $0.22 \mu \mathrm{m}$ filter and loaded into the column. The column was washed with starting buffer $(50 \mathrm{mM}$ sodium phosphate buffer $\mathrm{pH} 7)$ to remove weakly bound impurities. The fusion protein was eluted from the column by using $50 \mathrm{mM}$ sodium phosphate and $1.5 \mathrm{M} \mathrm{KCl} \mathrm{pH} \mathrm{7.} \mathrm{Purified} \mathrm{protein} \mathrm{was} \mathrm{characterized}$ based on its molecular weight and identity by SDS PAGE and Western Blotting Methods. Protein binichoninic assay was used to quantify the purified protein by using Bovine Serum Albumin.

\section{E. Antiproliferation Assay}

MCF-7 cells (obtained from mammalian cell culture laboratory, Indonesian Institutes of Sciences) were thawed and washed with $9 \mathrm{~mL}$ of DMEM medium containing penicillin (100 units $/ \mathrm{mL})$ and streptomycin $(100 \mathrm{mg} / \mathrm{mL})$. Cells were grown in the same medium containing $10 \%$ fetal bovine serum (FBS) at $37^{\circ} \mathrm{C}$ and $5 \% \quad \mathrm{CO}_{2}$. After $90 \%$ of confluency, the cells were washed with phosphate buffer saline (1.15 g Na2HPO4; $0.2 \mathrm{~g} \mathrm{KH} 2 \mathrm{PO} 4 ; 8 \mathrm{~g} \mathrm{NaCl}$ and $0.2 \mathrm{~g}$ $\mathrm{KCl}$ perliter, $\mathrm{pH}$ 7.2) and detached with $500 \mu \mathrm{L}$ of trypsin$\operatorname{EDTA}(0.25 \%$ trypsin in $0.53 \mathrm{mM}$ EDTA $)$ at $37^{\circ} \mathrm{C}$ for $5 \mathrm{~min}$. The cells were transferred into a 96 well (3000 cell/well) or 24 well plate $(15.000 /$ well) for further study. The cells were grown overnight in DMEM media containing penicillinstreptomycin with 5\% FBS, washed with $100 \mu \mathrm{L}$ of PBS and treated with $1 \mu \mathrm{M}$ tamoxifen (Merck) overnight. Further treatment was applied by various concentration of hIFN $\alpha-2 b$ for 5 days. rhIFN $\alpha-2 b$ standard was applied to validate the assay. The treatment conditions were based on a report by Lindner and Borden [20] with some modifications. Treated cells in 96 well plates were washed twice with $100 \mu \mathrm{L}$ of PBS. $100 \mu \mathrm{L}$ of DMEM with $5 \%$ FBS containing MTT (with final concentration $0.5 \mathrm{mg} / \mathrm{mL}$ ) was added to each well. Cells were then incubated for 3 hours and the medium was discarded. Formazan crystals formed at the bottom of the well were dissolved in $100 \mu \mathrm{L}$ of SDS $10 \%$. The cells were incubated for overnight. The reaction was stopped by $0.01 \mathrm{M}$ $\mathrm{HCl}$ and dissolved formazan was measured at $570 \mathrm{~nm}$. The percentage of the viable cell was compared to control (untreated cells). The experiments were done in triplicates in three dependent experiments [21].

\section{RESULTS AND DISCUSSION}

The fusion protein was produced extracellularly in Pichia pastoris. The codon optimized ORF encoding fusion protein was constructed synthetically. The synthetic ORF encoding HSA-hIFN $\alpha$-2a was 2292 bp in size and inserted in pUCIDT-AMP vector with ampicillin as a selectable marker. As shown in Fig. 1, the constructed sequence was consists of $X h o I$ and EcoRI as restriction sites, protease cleavage site of alpha-factor signal sequence in $\mathrm{pPICZ} \alpha \mathrm{B}$ and ORF encoding human interferon alpha2a that was fused with human serum albumin ORF at its C terminus (Fig. 1). Zhao et al (2008) reported that $\mathrm{N}$ terminus of hIFN $\alpha 2 \mathrm{~b}$ directly fused to $\mathrm{C}$ terminus HSA resulted in heterogenicity, we applied altering the orientation by fused HSA into $\mathrm{C}$ terminus of hIFN $\alpha-2 \mathrm{a}$. It was identified that the heterogenicity of hIFN $\alpha-2 b-\mathrm{HSA}$ caused by disruption of disulfide bridge formation between Cys1 and Cys98 so that the fusion protein was unstable and prone to form aggregates [19]. To avoid the immunogenicity of the fusion protein, we eliminated the linker between the two proteins.

pPICZ $\alpha \mathrm{B}$ was used as expression vector that contains $\alpha$ factor secretion signal. The ORF constructed to be in frame with $\alpha$-factor signal sequence to produce extracellular protein and applied sub cloning. The sub cloning was performed to insert the ORF into expression vector pPICZ $\alpha \mathrm{B}$ expression vector contains tigthly regulated $A O X 1$ promoter that strongly repressed by glucose, glyserol or ethanol [22], [23], [24]. As described in vector map, the processing of $\alpha$-factor matting signal sequence in pre fusion protein is performed by KEX2 and STE13 gene products. $K E X 2$ cleavage occuring between arginine and glutamine in the sequence Glu-Lys-Arg-Glu-Ala-Glu-Ala. The Glu Ala repeats are furtherly cleavage by STE13. The ORF flushed with KEX2 cleavage site to obtain fusion protein with $\mathrm{N}$ native terminus hIFN $\alpha-2$ a.

Transformation in E. coli XL1 blue resulted in 101 transformants in low salt LB agar containing zeocin as selection media. Only 6 transformants harboring recombinant plasmid as expected. Molecular weight and restriction site characterizations of transformants number 1 showed that recombinant plasmid containing the ORF with correct size as demonstrated in Fig. 2 (A). The recombinant plasmid was further linearized by using $S a c \mathrm{I}$ and purified by phenol chloroform precipitation as showed in Fig. 2 (B).

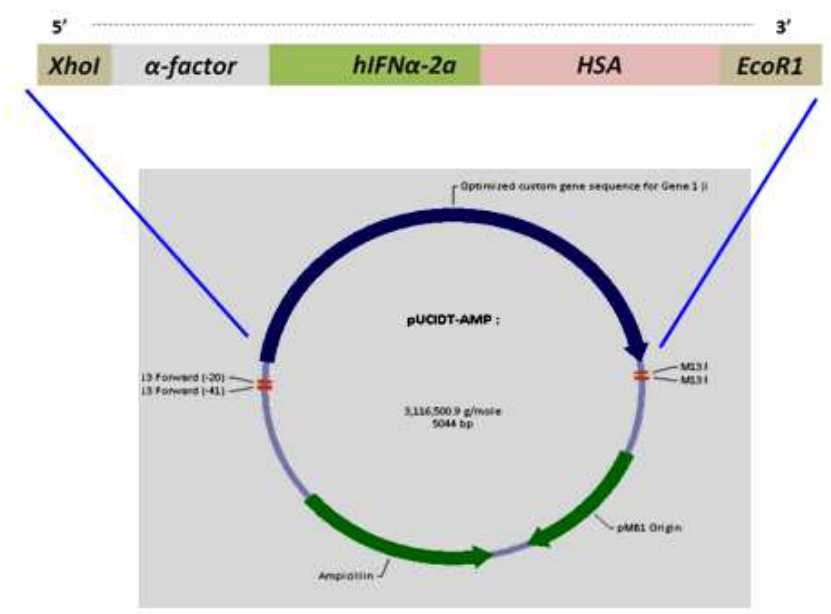


Fig. 1 The construction of synthetic ORF encoding fusion protein

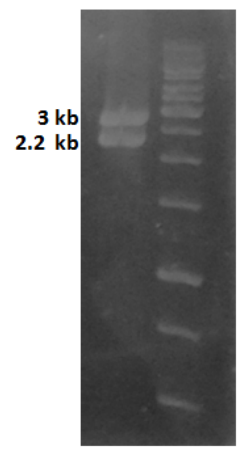

A

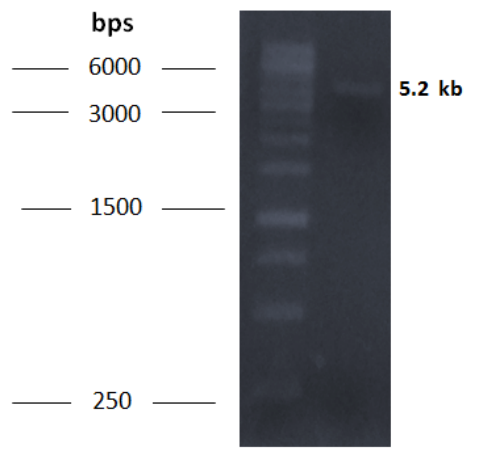

B
Fig. 2 Recombinant plasmid characterization, A. Characterization of recombinant plasmid containing fusion protein ORF by XhoI and EcoRI restriction enzyme, B. Linearization of recombinant plasmid containing fusion protein ORF by $S a c I$ restriction enzyme

Purified recombinant plasmid containing fusion protein ORF was transformed into Pichia pastoris by electroporation and transformants were selected in the gradual concentration of zeocin.

The ORF was transformed into GS115 and SMD1168 strains. GS115 is a mutant that has a mutation in the histidinol dehydrogenase gene (his4) that prevents it from synthesizing histidine. As host-specific proteases determine effective production and purification of heterologous proteins from yeasts, this research also used SMD1168 as protease deficient mutant that lack of proteinase A (pep4) activity.

There were 11 selected transformants ( 9 transformants of SMD1168 and 2 transformants of GS115) to be observed in expression analysis. Protein overproduction was performed by applying methanol as an inducer. All transformants gave a positive result at 24 and $48 \mathrm{~h}$ of harvesting time using mouse anti HSA antibody in dot blot analysis (data not shown). This result strongly indicated that the targeted fusion protein was produced in Pichia pastoris GS115 and SMD1168. Further characterization was undertaken by SDS PAGE and Western Blot analyses based on protein molecular weight and identity. The electrophoregram profile informed that each strain produced a fusion protein with 85 $\mathrm{kDa}$ in size. We also observed the protein overproduction at two different harvesting time (24h and 48h) for SMD1168 transformants as shown by Fig. 3 (A, B, C, D) and GS115 transformants as shown by Fig. $3(\mathrm{E}, \mathrm{F})$, The production generated better protein level at $48 \mathrm{~h}$ (Fig. $3 \mathrm{C}$ and $\mathrm{E}$ ). Several bands that also produced with a smaller size on Western Blot analysis indicated that the fusion protein was degraded by protease activity.

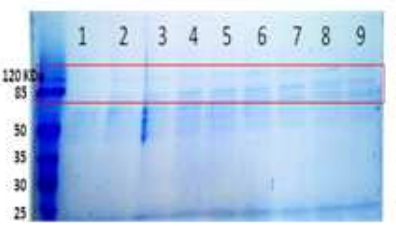

(A)

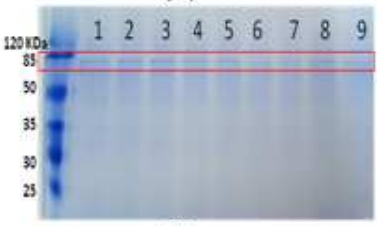

(C)

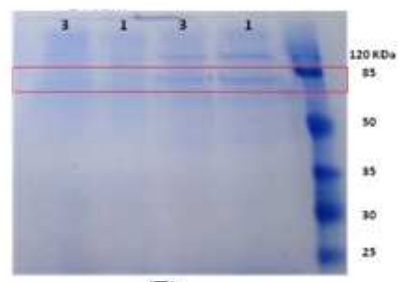

(E)

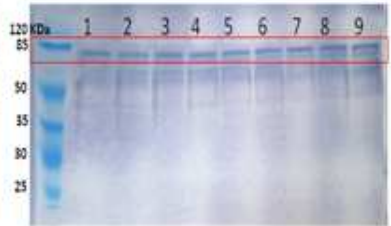

(B)

(D)

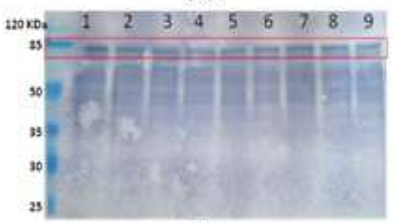

Fig. 3 Characterization of the fusion protein. $A$ and $B=$ SMD1168 transformant no 1 to 9 at $24 \mathrm{~h}$ of harvesting time; $\mathrm{C}$ and $\mathrm{D}=$ transformant no 1 to 9 at $48 \mathrm{~h}$ of harvesting time; $\mathrm{E}$ and $\mathrm{F}=\mathrm{GS} 115$ transformant no 1 and 3 at $24 \mathrm{~h}$ and $48 \mathrm{~h}$ of harvesting time. The bands in the red box were the fusion protein

The secreted fusion protein degraded due to activity of extracellular proteases, cell bound proteases or intracellular proteases from lysed cells. Proteolysis is a major problem of protein production in Pichia pastoris because it reduces protein yield, deprives biological activity and contaminates the product with degradation fragments that have similar physicochemical and affinity characteristic [25]. There are several proteases that mostly produced in Pichia pastoris, namely proteinase $\mathrm{A}$, proteinase $\mathrm{B}$, carboxylpeptidase and aminopeptidase [26]. Several strategies to inhibit proteolysis activity have been reported, such as protein engineering [27], optimization of fermentation parameters $(\mathrm{pH}$, temperature and growth rate), modification of culture media composition (rich media, additional amino acid or peptone, lowering salt concentration as well as soytone addition) [19] and the use of protease deficient strain. Ahmed [23] stated that in some cases optimization of fermentation and protein enginnering have been failed to overcome the proteolysis problem so the use of protease deficient strain can be more promising. Its use not only reduces proteolysis that lowering protein yield in production but also avoid time consuming and complicating downstream process due to degradation product [23], [26].

In this research, the use of SMD1168 to produce fusion protein was still not completely deprived the proteolysis problem. Protein profile on electrophoregram still showed some degradation fragments which indicated that the knock out of pep4 that encodes proteinase A did not completely eliminate the proteolysis. pep4 encodes a major vacuolar aspartyl protease which is able to activate itself as well as other proteases such as carboxypeptidase Y (PRC1) and proteinase B (pRb1) [26]. This indicated that the 
degradation that still occured in our fusion protein did not caused by proteinase A or B as well as PRC1.

Several studies reported the role of yapsin 1 protease in degradation of recombinant protein produced in the host [28], [29], [30], [31]. Yapsin is a glycosylphosphatidylinositol (GPI)-linked aspartyl proteases family that have the ability to cleave protein at the $\mathrm{C}$-terminal side of basic amino acids. Kerry et al [30]. reported that HSA produced in Saccharomyces cerevisiae was truncated by yapsin1 (YPS1) protease. This report was in line with Yao et al [32] that stated YPS1 disruption gave a partial reduction of HSA degradation. $\mathrm{Wu}$ [31] also claimed that the disruprion of YPS 1 and pep4 reduced proteolytic degradation of secreted HSA-parathyroid hormone in Pichia pastoris GS115.

Protease inhibitor was also used to reduce the protease activity. The inhibitor was added at 0 to $3 \mathrm{~h}$ after initial production to obtain optimal condition. To check the proteolysis profile that results in smaller protein fragments, Western Blot analysis was used. The result informed that the best production level was achieved at $3 \mathrm{~h}$ after initial production (Fig. 4). The combination of SMD1168 strain and protease inhibitor reduced proteolysis signifficantly. The protease inhibitor is able to inhibit aspartic proteases, as well as serine and cysteine proteases. This strongly indicated that the proteolytic activity of yapsin as aspartic protease was inhibited by antiprotease so that the presence of degradation fragments was minor. It was found that the addition of protease inhibitor at 0 to 30 minutes after expression may result in $A O X 1$ promoter repression so the protein did not be produced. So far there was no study reported the $A O X 1$ repression caused by protease inhibitor. ImageJ software was applied (free downloaded at http://imagej.en.softonic.com) to determine best expression level (data not shown). The highest Area Under the Curve (AUC) was obtained in $3 \mathrm{~h}$ of inhibitor addition. Protein purification by affinity chromatography column showed that the fusion protein has been purified as shown in Fig. 5. The protein quantity determination informed that the yield of the fusion protein was $14 \mathrm{mg} / \mathrm{L}$. The total yield of our fusion protein was $14 \mathrm{mg} / \mathrm{L}(\mathrm{OD} 600=2)$. Because this research still used low OD in protein production, so the result was lower than another study that produced HSA-VEGF165b fusion protein with $275 \mathrm{mg} / \mathrm{L}(\mathrm{OD} 600=20)$.

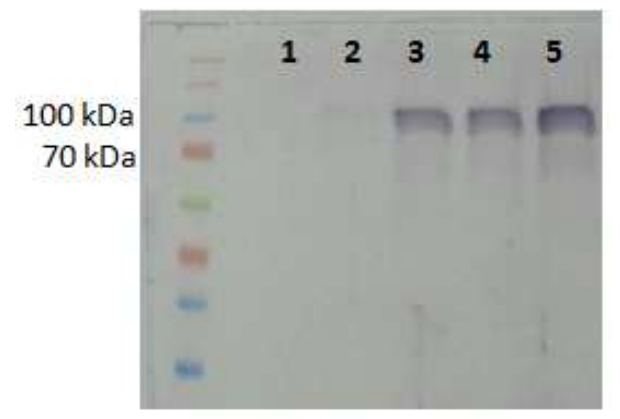

Fig. 4 Overproduction of fusion protein by using protease inhibitor. The protease inhibitor added at $1=0 \mathrm{~h}, 2=30 \mathrm{~min}, 3=1 \mathrm{~h}, 4=2 \mathrm{~h}, 5=3 \mathrm{~h}$ after initial production

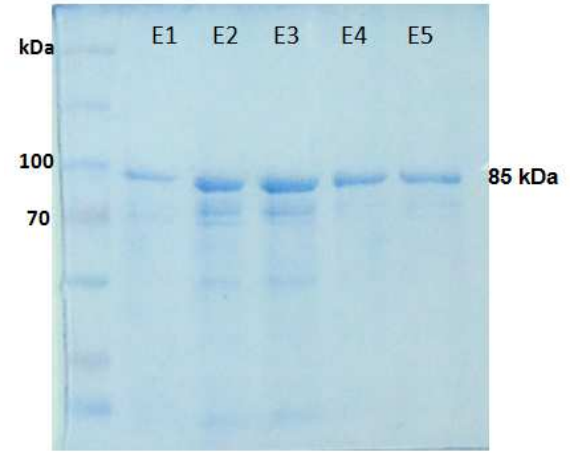

Fig. 5 Purification of the fusion protein by using affinity chromatography. E1 to $5=$ eluate $1,2,3,4$ and 5 .
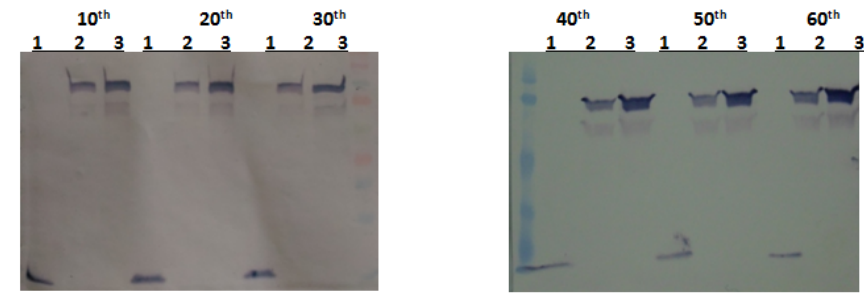

Fig. 6 Stability of fusion protein production in $60^{\text {th }}$ generation $1=$ control , $2=$ fusion protein from GS115 and $3=$ fusion protein from SMD1168

The ORF expression was monitored in Pichia pastoris until $60^{\text {th }}$ generation. The expression stability is the most important thing in protein production. ORF expression stability was performed to monitor the stability integration of the ORF into Pichia pastoris genome. The stable transformants were generated by homologous recombination between the transforming ORF and regions of homology within the genome [33]. There was no significant difference in expression among the generations which strongly indicated that the fusion protein production of recombinant Pichia pastoris was stable (Fig. 6). The stability analysis also informed that SMD1168 gave better expression level comparing to GS115.

It has been known that protein modification often results in decreasing biological activity due to protein structure alteration. The effect of HSA fusion into hIFNa-2a antiproliferative activity by using MCF-7 cell line. MCF-7 is human breast adenocarcinoma and ER positive cell line. At this preliminary antiproliferative assay, unmodified hIFN $\alpha$ 2a from previous research was used as a standard. There was lowering antiproliferative activity of fusion protein comparing to its unmodified form (Fig. 7). The antiproliferative activity was dose dependent. 


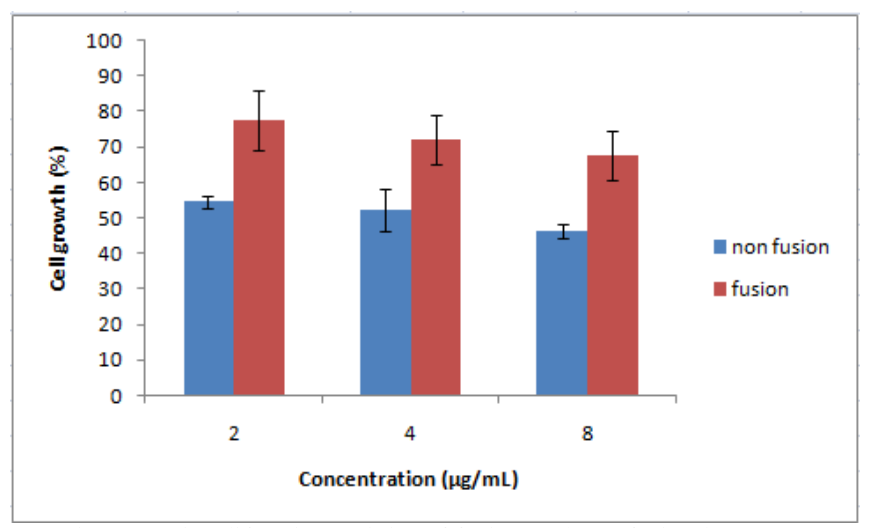

Fig. 7 Antiproliferative activity of fusion and non fusion hIFN $\alpha-2 a$

The biological activity of interferon type I occurs through the IFNAR1 and IFNAR2 receptors [34,35]. The two receptor-associated tyrosine kinases Tyk 2 and Jak 1 will be activated, which subsequently recruit and activate the cytoplasmic factors belonging to the signal transducer and activator of transcription (STAT) family of proteins [36,37]. STAT subsequently translocated with interferon regulating factor-9 (IRF-9 or P48) to the cell nucleus. The protein complex known as IFN-Stimulated Gene Factor 3 (ISGF-3) can activate interferon stimulating response element (ISRE). Two phosporylated sub unit of Stat 1 form alpha activation factor that binds to gamma activation sequence (GAS). These induce transcription of hundreds of interferonstimulated genes (ISGs) that involve in antiproliferative [38, 39], [40].

Preliminary antiproliferative determination performed using a combination with tamoxifen (tmx). According to the previous study, tmx can modulate the anticellular response to rhIFN $\alpha-2$ rather than the opposite. Tamoxifen is a cellpermeable and reversible inhibitor of protein kinase C. It induces apoptosis in human malignant glioma cell lines and inhibits prostate cancer cell growth by induction of p21 protein. Tamoxifen is a potent synthetic anti-estrogenic agent. It is cytostatic for estrogen-dependent cell line. Estradiol binds to estrogen receptor (ER) in ER positive cell and induces transcription to promote growth. Tamoxifen competes with estrogen for binding to the receptor so growth inhibition occurs [38].

The antiproliferative determination showed that fusion protein has lower activity comparing to unmodified form. The result informed that at various concentrations used, the activity of the fusion proteins was about $20 \%$ lower. It is too early to state that our fusion protein has no much different activity with the unmodified form, so further analysis may need to complete and strengthen the result. Our result was in line with other studies about modified hIFN $\alpha 2$. Bailon et al. reported that pegylated $\mathrm{hIFN} \alpha-2 \mathrm{a}$ retains only $7 \%$ of antiviral activity comparing to unmodified form [6]. Subramanian et al (2005) also stated that HSA fusion hIFN $\alpha$-2b was less potent comparing to unmodified form but gave greater antiviral activity comparing to pegilated $\mathrm{hIFN} \alpha$ 2b [16].

Currently, hIFN $\alpha-2 \mathrm{a}$ is still a potential therapeutic protein to be developed. Many diseases stated the urgency of using the protein in future direction treatment, such as hepatitis B and C [41], [42], systemic lupus erythematosus [43] and renal cell carcinoma [44]. HSA fusion protein is one of modification studies to develop hIFN $\alpha-2 \mathrm{a}$. The protein will be further characterized and pharmacokinetic determined.

\section{CONCLUSIONS}

The higher molecular weight of interferon alpha2a by human serum albumin fusion was successfully produced in Pichia pastoris with $85 \mathrm{kDa}$ in size. The ORF expression was stable until $60^{\text {th }}$ generations. The yield of purified form was $14 \mathrm{mg} / \mathrm{L}$. At preliminary antiproliferative activity determination, the fusion potein has a potential activity that only $20 \%$ lower comparing to unmodified form.

\section{ACKNOWLEDGMENT}

This research was funded by Riset Unggulan LIPI 20152016 from Indonesian Institute of Sciences. The authors would like to thank Adi Santoso, Syaipul Bahri and Syubbanul Wathon from Research Center for Biotechnology, Indonesian Institute of Sciences for their kind assistance in this research.

\section{REFERENCES}

[1] J. Ferlay, J. Soerjomataram, R. Dikshi, S. Eser, C. Mathers, M Rebelo, D.M. Parkin, D. Forman and F. Bray, "Cancer incidence and mortality worldwide: Sources, methods and major patterns in GLOBOCAN 2012”, Int J Cancer, vol. 136, no.5, pp. E359-E386, 2015.

[2] WHO and CDC fact sheets 2015, available at www.who.intand www.cdc.gov

[3] N. Ceaglio, M. Etcheverrigaray, R. Kratje and M.Oggero, "Novel long-lasting interferon alpha derivatives designed by glycoengineering", Biochimie, vol. 90, pp. 437-449, 2008.

[4] Y.S. Wang, S. Youngster, M. Grace, J.Bausch, R. Bordens and D.F. Wyss, "Structural and biological characterization of pegylated recombinant interferon alpha-2b and its therapeutic implications", Adv Drug Deliver Rev, vol. 54, pp. 547-570, 2005.

[5] F. Kanwar, F. Danesh and S.S.Chugh, "Contribution of Proteoglycans Towards the Integrated Functions of Renal Glomerular Capillaries A Historical Perspective", Am J Pathol, vol.171, pp. 9-13, 2007.

[6] P. Bailon, A. Palleroni, C. Schaffer, C.L. Spence, W.J. Fung, J.E. Porter, G.K. Ehrlich, W. Pan, Z.X. Xu,M.W. Modi, A. Farid, and W. Berthold, " Rational Design of a Potent, Long-Lasting Form of Interferon: A $40 \mathrm{kDa}$ Branched Polyethylene Glycol-Conjugated Interferon r-2a for the Treatment of Hepatitis C", Bioconjugate Chem, vol. 12, pp.195-202, 2001

[7] K.R. Reddy, M.W. Modi, and S. Pedder, "Use of peginterferon alpha-2a $40 \mathrm{KD}$ (Pegasys) for the treatment of hepatitis C", Adv Drug Delivery Rev, vol. 54, pp. 571-86, 2002.

[8] H.L. Zhao, X.Q. Yai, C. Xue, Y. Wang, X.H. Xiong, and Z.M. Li, " Balancing the Pharmacokinetics and Pharmacodynamics of Interferon- $\alpha 2 b$ and Human Serum Albumin Fusion Protein by Proteolytic or Reductive Cleavage Increases Its in Vivo Therapeutic Efficacy", Mol Pharmaceutic, vol. 9, pp. 664-670, 2012.

[9] H.L. Zhao, X.Q. Yai, C.Xue, Y.Wang, X.H.Xiong, and Z.M. Liu, "Increasing the homogeneity, stability and activity of human serum albumin and interferon-a2b fusion protein by linker engineering", Protein Expres Purif, vol. 6, pp.73-77, 2008.

[10] A. Duttaroy, K. Palanisamy, L. Blaire, H. Schneider, O.K. Pickeral, C. Chen, G. Zhang, S. Kaithamana, M. Singh, R. Schulingkamp, D. Crossan, J. Bock, T.E. Kaufman, P. Reavey, M.C. Barber, S.R. Krishnan, A. Garcia, K. Murphy, J.K. Siskind, M.A. McLean, S. Cheng, S. Ruben, C.E. Birse and O. Blonde, "Development of a Long-Acting Insulin Analog Using Albumin Fusion Technology", Diabetes, vol. 54, pp. 251-258, 2005.

[11] M.R. Joshi, N. Yao, K.A. Myers and L. Zhiyu, "Human Serum Albumin and p53-Activating Peptide Fusion Protein Is Able to Promote Apoptosis and Deliver Fatty Acid-Modified Molecules", pLOS ONE, vol. 8, no.11, pp. 1-14, 2013. 
[12] S. Schulte, "Use of albumin fusion technology to prolong the halflife of recombinant factorVIIa", Thromb Res, vol. 122 Suppl. 4, pp. S14-S19, 2008.

[13] M.W. Nolte, T.C. Nichols, J.M. Cohrs, E.P. Merricks, I.Pragst, S. Zollner and G. Dickneite, "Improved kinetics of rIX-FP, a recombinant fusion protein linking factor IX with albumin in cynomolgus monkeys and hemophilia B dogs", J Thromb Haemost., August ; vol. 10, no. 8, pp. 1591-1599. 2008.

[14] Y. Peng, L. Deng, Y. Ding, Q. Chen, Y. Wu, M. Yang, Y. Wang and F. Qiang,"Comparative Study of Somatostatin-Human Serum Albumin Fusion Proteins and Natural Somatostatin on Receptor Binding, Internalization and Activation", PLOS ONE, vol. 9, no.2, pp. 1-9, 2014.

[15] R.Y Zhu, X. Xin, H.Y. Dai, Q. Li, J.Y. Lei, Y. Chen and J.Jin, "Expression and purification of recombinant human serum albumin fusion protein with VEGF165b in Pichia pastoris", Protein Expres Purif, vol.85, pp. 32-37, 2012.

[16] M.G. Subramanian, M. Fiscella, and A.L. Smith, "Albinterferon $\alpha-2 b$ : a genetic fusion protein for the treatment of chronic hepatitis C", Nat Biotechnol, vol. 25, pp. 1411-1419, 2007.

[17] Y.F. Yang, H.Y. Yuan, N.S. Liu, X.L.Chen, B.Y. Gao, H. Lu, Y. Li, Construction, expression and characterization of human interferon $\alpha 2 b-(G 4 S) n$-thymosin $\alpha 1$ fusion proteins in Pichia pastoris, World J Gastroenterol, vol. 11, no.17, pp. 2597-2602, 2005.

[18] Y.Fu, Z.Yu, "Long Acting human Interferon Analog", US Patent 0051859. 2006.

[19] H.L. Zhao, C. Xue, J.L.Du, M.Ren, S.Xia and Z.M.Liu, "Balancing the Pharmacokinetics and Pharmacodynamics of Interferon- $\alpha 2 b$ and Human Serum Albumin Fusion Protein byProteolytic or Reductive Cleavage Increases Its in Vivo Therapeutic Efficacy", Mol pharmaceutic, vol. 9, pp. 664-670, 2012.

[20] D.J. Lindner and E.C. Borden, "Synergistic Antitumor Effects of a Combination of Interferon and Tamoxifen on Estrogen ReceptorPositive and Receptor- Negative Human Tumor Cell Lines In Vivo and In Vitro", J interferon cytokine res, vol. 17, pp. 681-693, 2007.

[21] E.P. Septisetyani,, R.A. Ningrum,, Y. Romadhani, P.H. Wisnuwardhani, and A. Santoso, "Optimization of sodium dodecyl sulphate as a formazan solvent and comparison of MTT assay with WST-1 assay in MCF-7 cells", Indonesian J Pharm, vol. 25, no.4, pp. 245-254, 2014.

[22] B. Gasser, M.G. Steiger, D. Mattanovich, Methanol regulated yeast promoters: production vehicles and toolbox for synthetic biology, Microb. Cell. Fact, vol 14, pp 1-3, 2015.

[23] N. Ahmed, M.A. Khan, N. Shahid, I.A. Nasir and A.U. Zafar, " One step purification of biological active human interleukin-2 protein produced in yeast (Pichia Pastoris)", African J Biotechnol, vol. 10, pp. 15170-15178, 2011

[24] J.M. Cregg, K.R. Madden, K.J. Barringer, G. Thill and C.A. Stillman "Functional Characterization of the Two Alcohol Oxidase Genes from the Yeast Pichia pastoris", Mol. Cell. Biol, vol.9, pp. 13161323.1989.

[25] S.M.Patrick, M.L. Fazenda, B. McNeil and L.M. Harvey, "Heterologous protein production using the Pichia pastoris expression system Yeast", vol.22, pp. 249-270, 2005.

[26] J. Sinha, B.A. Plantz, M. Inan and M.M. Meagher,"Causes of proteolytic degradation of secreted recombinant proteins produced in methylotrophic yeast Pichia pastoris: case study with recombinant ovine interferon-tau", Biotechnol Bioeng, vol. 89, no. 1, pp. 102-112, 2005

[27] M. Gustavsson, J. Lehtio and S. Denman, "Stable linker peptides for a cellulose- binding domain-lipase fusion protein expressed in Pichia pastoris", Protein Eng, vol.14, no.9, pp. 711-715, 2001.

[28] Y. Bourbonnais, C. Larouche and G.M. Tremblay, "Production of full-length human pre-elafin, an elastase specific inhibitor, from yeast requires the absence of a functional yapsin 1 (Yps1p) endoprotease", Protein Expres Purif, vol. 20, no. 3, pp.485-491, 2000.

[29] H.A. Kang, S.K. Rhee, M.J. Sohn and J.Y. Kim, "Hansenula porlymorpha yapsin deficient mutant strain and process for the preparation of recombinant proteins", International Application Number: PCT/KR2003/001279, 2004

[30] S.M. Kerry-Williams, S.C. Gilbert, L.R. Evans and D.J. Ballance, "Disruption of the saccharomyces cerevisiae YAP3 gene reduces the proteolytic degradation of secreted recombinant human albumin". Yeast, vol. 14, no.2, pp. 161-169, 1998.

[31] M. Wu, Q. Shen, Y. Yang, S. Zhang, W. Qu, J. Chen, H. Sun and S. Chen, "Disruption of YPS1 and PEP4 genes reduces proteolytic degradation of secreted HSA/PTH in Pichia pastoris GS115", J Ind Microbiol Biotechnol”, vol.40, pp.589-599, 2013.

[32] X.Q. Yao, H.L. Zhao, C. Xue, W. Zhang, X.H. Xiong, Z.W. Wang, X.Y. Li, Z.M. Liu, "Degradation of HSA-AX15(R13 K) when expressed in Pichia pastoris can be reduced via the disruption of YPS1 gene in this yeast", J Biotechnol, vol.139, no.2, pp.131-136, 2009.

[33] B. Byme, "Pichia pastoris as an expression host for membrane protein structural biology", Curr. Opin. in struc. biol, vol 32, pp. 9-17, 2015.

[34] Y.A. Hsu, C.C. Huang, Y.J. Kung, H.J. Lin, C.Y.Chang, K.R.Lee and L. Wan, "The anti-proliferative effects of type I IFN involve STAT6-mediated regulation of SP1 and BCL6", cancer lett, vol. 375, no.2, pp. 303-312, 2016

[35] B.S, Parker, J. Rautela and P.J. Hertzog, "Antitumour actions of interferons: implications for cancer therapy", Nature Cancer Rev, vol.26, pp. 131-144. 2016.

[36] L. Zitvogel, L. Galluzzi, O. Kepp, M.J. Smyth and G. Kroemer, "Type I interferons in anticancer immunity", Nat. Rev. Immunol, vol 15, no 7, pp 405-414, 2015.

[37] Y. He, J. Huang, P. Wang, X. Shen, S. Li, L, Yang, W. Liu, A.Suksamrarn, G. Zhang and F. Wang, "Emodin potentiates the antiproliferative effect of interferon $\alpha / \beta$ by activation of JAK/STAT pathway signaling through inhibition of the $26 \mathrm{~S}$ proteasome", Oncotarget, vol. 7, no.4, pp 4664-4679, 2015.

[38] R.A. Ningrum, P.H. Wisnuwardhani, A. Santoso and N. Herawati, "Antiproliferative Activity of Recombinant Human Interferon alpha2b on MF-7 cell line", Indonesian J. pharm, vol. 26, no. 2, pp 86-93, 2015.

[39] H. Rachmawati, A. Jessica, Y.C. Sumirtapura, D.S. Retnoningrum, A. Adlia and R.A.Ningrum, "Removing Cystein Group on Interferon Alpha $2 b$ at position 2 and 99 does not diminish antitumor activity of the protein, even better", Scientia Pharmaceutica, vol, 84, pp. 113130, 2016.

[40] S. Wathon, S. Budiarti, P. Wisnuwardhani, N. Herawati, A.Santoso and R.A. Ningrum, "Stability of recombinant human interferon alpha2b produced in methilotropic Pichia pastoris", Int. J. Res Pharm. Sci, vol 6, no.4, pp 312-320, 2015.

[41] A. Tawasa, T. Kanda and O.Yokosuba, "Current and future directions for treating hepatitis B virus infection", World Journal of Hepatology, vol 7, no 11, pp 1541-1552, 2015.

[42] S. Petta and A. Craxi, "Current and Future HCV Therapy : Do we still neeed other anti-HCV Drugs?", Liver International,vol 35, no s1, pp 4-10, 2015.

[43] T.A. Gottschalk, E.T santikos and ML. Hibbs, "Pathogenis inflammation and its therapeutic targeting in systemic lupus erythmatosus", Front. Immunology, 28 Oktober 2015. http://dx.doi.org/10.3389/fimmu.2015.00550

[44] O. Smaletz, "Current management and future directions in the treatment of advanced renal cell carcinoma-a latin american perspective: 10 years in review", International Braz. J. Urol, vol 41, no 5, pp 835-843, 2015. 